\title{
IAMJ
}

INTERNATIONAL

AYURVEDIC

MEDICAL JOURNAL

ISSN: $2320-5091$

Impact Factor: 6.719

\section{AYURVEDIC CONCEPT OF VAGINAL DISCHARGE: (YONIGATA STRAVA)}

\author{
Nisha Baban Pawshe ${ }^{1}$, Tinku-Ganesh P. Khalache ${ }^{2}$ \\ ${ }^{1}$ PG Scholar, Department of Prasuti Tantra, \\ ${ }^{2}$ (Associate Professor), Dept. Of Streerog and Prasutitantra, \\ Hon. Shri. Annasaheb Dange Ayurved Medical College and Research \\ Centre, Ashta.Dist -Sangli, Maharashtra, India
}

Corresponding Author: nishapawshe@gmail.com

https://doi.org/10.46607/iamj2509112021

(Published Online: November 2021)

Open Access

(C) International Ayurvedic Medical Journal, India

Article Received: 17/10//2021 - Peer Reviewed: 31/10/2021 - Accepted for Publication: 02/11/2021

\section{Check for updates}

\section{ABSTRACT}

Vaginal discharge is one of the major problems encountered in gynaecological practice. It is a very common condition that has been experienced by most women of all ages, especially in childbearing or reproductive age.

Vaginal discharge is a condition that causes great discomfort to a woman and hampers her normal activity. It is believed that vaginal discharges produce loss of strength \& confidence, also there is the presence of fear that it may be due to malignancy. Nowadays it is essential to study differential diagnosis of vaginal discharge.

In Ayurvedic texts, various conditions giving rise to white discharge per vaginum had been described but the subject was never dealt with as a separate entity. Therefore, in this study, an effort has been put forth to make a conceptual study covering almost all the aspects of Yonigata Strava as per Ayurveda as well as per modern.

Keywords: Leucorrhoea, Vaginal Discharges, Yonigata Strava.

\section{INTRODUCTION}

A healthy woman is a promise of a healthy family. In different phases of a women life, from puberty to menopause, the concept of healthy yoni has been mentioned in Ayurveda as well as in modern. 
Normal physiological vaginal discharge is a white or clear, non-offensive discharge that can vary over time. It is thick and sticky for most of the menstrual cycle but becomes clearer, wetter, and stretchy for a short period around the time of ovulation. It is heavier and more noticeable during pregnancy, with contraceptive use and with sexual stimulation. It decreases in volume at menopause due to a fall in estrogen levels. Abnormal vaginal discharge is characterized by a change in colour, consistency, volume, odour and may be associated with symptoms such as itching, soreness, dysuria, pelvic pain, or intermenstrual or postcoital bleeding.

Vaginal discharge is one of the most common problems faced by many women. Women do not give much attention to this problem unless and until it will make the patient feel uncomfortable in their day-today life. It is not a disease but a symptom, which is seen in most the disease as symptoms. So, in this study, an effort has been put forth to make a conceptual study covering almost all the aspects of the Yonigata strava.

\section{DESCRIPTION: -}

Normal vaginal discharge may appear clear, cloudy, white and without any type of smell. It is physiological in the following conditions- Prakruta strava:

1. In newborn female

2. At the time of puberty

3. At the time of ovulation

4. During coitus

5. During Pregnancy:

\section{Garbhini-}

तत्रप्रथमेमासिकललंजायचे 1

खेट:श्लेष्मा, मेंखेटभूतआणिश्लेष्मलदृशइत्यर्थ: !

- च. शा. ४/९चक्र.टीका.

Such physiological conditions don't need treatment. Any changes in colour, consistency, amount, the smell of discharge may be a sign of Vaginal infection. In Ayurvedic Samhitas, all gynaecological disorders come under the heading of Yonivyapat. Vaginal discharges mean Yoni strava is seen as a symptom in various Yonivyapat and some diseases.

\section{Etiology}

मिथ्याचारेणता:स्त्रीणांप्रदुष्टेनार्तवेनच !
जायचेबीजदोषाच्चदैवाच्चश्रृणुता:पृथक:!

-च.चि.30/8

Abnormal diet and mode of life, abnormalities of $A r$ tava and Beeja (either ovum or sperms and both) and Daivakop (anger of God), are the general Nidan of Yonivyapat. Based on clinical features white discharge seems to be a Kaphaja disorder of a female's genital organ because Kapha dosha is the main causative factor for any discharge so it is said that Kaphaprakopa. (aggravation) According to "Ashrayashrayisiddhanta" in Ayurveda Rasa and Kapha are in close relation, hence Rasa dushti can be considered as one of the causes of Vaginal discharge.

\section{TYPE OF VAGINA DISCHARGE.}

$1 T A N U$ - (This as against thick)

Here the discharge is Tanu i.e., watery. If Kaphaprakopa accompanied with Pittaprakopa of its Drava guna. this type of discharge occurs.

2. PICHCHILA- (slippery, lubricous, slimy)

Discharge is a mucoid one. When kapha-prakopa especially of its Pichchila \& Snigdhaguna accompanied with Vataprakopa of its Chalaguna this type of discharge occurs.

3) STHANA - (Collected into a mass thick, bulky and gross)

Collected into a mass, thick bulky gross here the discharge is thick \& curdy. It denotes Kaphaprakopa in a stage of Samawastha.

4) AVILA TANTULA - (like water in a trench around the roots of a tree, fibrous, sticky).

Here the discharge is a Muco- purulent one. If Kaphaprakopa of Samawastha is accompanied with Vataprakopa. This type of discharge occurs.

5) DURGANDHI PEETA - (Offensive, yellowish)

Here the discharge is a purulent one. This type of discharge is seen if Kaphaprakopa of Samawastha is accompanied by Pitta prakopa.

Vaginal discharge varies in its characteristics according to the Dosh dushti at its base. If one takes into consideration the type of discharge, it is easy to understand the underlying pathology to a certain extent. The genital tract is the seat of a lesion and discharge is just a symptom there. Hence, we will note the vari- 
ous conditions in which different types of vaginal discharge occurs.

\section{VARIOUS CONDITIONS-}

\section{Kaphaja Yonivyapat-}

Kapha dosha vitiated due to the excessive indulgence of Abhishyandi (moisture-producing substances) like diets and regimens, reaches the yoni and causes Pandupichilasrava (whitish mucoid menstruation), Kaṇụ (itching) and Alpavedana (low-grade pain) ${ }^{2}$. Vagbhata has included yellowish discolouration of vaginal discharge and Avedana (without pain) ${ }^{3}$ while Susruta has given only local symptoms of Pichilata of yoni (vagina with mucoid secretions), Kandu (itching) and Sheetalata (coldness in the vagina).

\section{Acharana or Vipluta -}

It is a condition due to the Krimis (microbes) formation resulting from yoni Adhāvana (noncleanliness of vulva and vagina) leading to Kandu (itching) in the vagina, But Susruta says that in Acharana, the woman gets hyperexcited even before the coitus, as well as much earlier than the husband along with other features of Kapha vitiation such as unctuousness and itching.

3. Atyananda - It is another condition in which the woman does not get satisfied with coitus; along with other Kaphaja symptoms like unctuousness and itching.

4. Aticharana - According to Acharya Charaka \&Vagbhata, it is characterized with Shopha (inflammation), Supti (numbness) \& Ruja (tenderness) due to Ativyvaya (excessive sexual act) while Acharya Susruta has indicated an inability to conceive along with Shleshmaja clinical features like unctuousness and itching these conditions resembles chronic cervicitis. ${ }^{8}$

5. Karnini - This is a condition caused by Kapha and Raktadushti. Charaka has described it as the effect of premature bearing down which causes chronic cervicitis due to infection of the lacerated cervix caused during Labour.

6 Upapluta - It is a condition characterised by whitish mucoid discharge along with other Vataja and Kaphaja lakshana such as Shwetpandustrava (white discharge) along with Toda (pricking pain). Charaka highlights the involvement of Garbhinicharya (antenatal dietetics and regimens) whereas Vagbhata didn't specify that.

\section{Paripluta -}

Charaka and Vagbhata explained that when a Pitta prakruti woman holds her Vega (natural urges) of Kṣavathu (sneezing) or Udgara (belching) during coitus, then pitta gets vitiated and mixes with Vayu reaches the yoni and produces its abnormalities like Neela Peeta strava (bluish or yellowish discharge), Shoonata (numbness), Sparshasahatva (tenderness) along with other systemic symptoms like Jwara (fever), Atisara (diarrhoea), Aruchi (anorexia) etc. While Susruta mentioned this condition with severe dyspareunia (Gramyadharmeruja,) along with other types of Anilavedana (vataja symptoms). ${ }^{11}$

\section{Sarvadhehikvichar}

1. Kaphajajwara - Rasaj vadhi Relation between Kapha and Rasa.

2. Kaphaj Pandu -. (रसोपिश्लेष्मवत्!) Relation between Kapha and Rasa.

3.Prameha - सामान्यंलक्षणंतेषांप्रभूताविलमूत्रता! Kaphavikruti and keldvrudhi

4. krimhi- Yonigatashwetasrava associated symptoms kanduta.

5.Raktagulma

योन्याःचाटालत्वम्, अपिचयोन्यादौर्गध्यमास्त्रावश्चोपजायते! 12

-च.नि.३/१४

There is foul-smelling mucopurulent discharge.

6. Phiranga -

तत्रबाह्यफिरड्गसस्याद्विस्फोटसदृशोल्परुका ${ }^{13}$

स्फुटितोव्रणवद्वेद्य :सखसाध्योड़पिसस्मृतः !

-भा. प्र.चि. ५९/५

It is like a blister with little pain after rupture an ulcer is formed here discharge is with Durgandhi.

7.KaphajaUpadamashe:

सकण्डूरै :शोथयुतैर्महभ्वि:शुकलैघनै :सत्रावयुतै :कफेना ${ }^{14}$

-मा.नि.४७/२

Madhavanidana says that the inflammation with itching, large, white, hard or with ulcers and white discharges is Updamshe due to kapha. 
8. Soma roga

स्रीणामतिप्रसड्गनशोकाच्चापिश्रमादपि|अभिचारिकयोगाद्वागरयोगात्तथैवच। ${ }^{15}$

आप:सर्वशरीरस्था:क्षुभ्यन्तिप्रस्रवन्तिचतस्यास्ताः:्रच्युताःस्थानान्मूत्रमार्गेत्रजन्तिहि॥
-भा०प्र०चि०६९/ /,

There is white, cold, odourless, painless \& excessive discharge present and she feels weak.

Table 1: Differential Diagnosis

\begin{tabular}{|l|l|l|l|l|}
\hline Tanu (watery) & Pichchila (Mucoid) & Sthana (thick, curdy) & $\begin{array}{l}\text { Avilla } \text { - Tantula } \\
\text { (Muco- purulent) }\end{array}$ & $\begin{array}{l}\text { Peeta Durgan- } \\
\text { dhi (purulent) }\end{array}$ \\
\hline Soma roga & Kaphajayonivyapat & Atyanandayonivyapat & $\begin{array}{l}\text { Karnini- } \\
\text { yonivyapat }\end{array}$ & Raktagulma \\
\hline Acharanayonivyapat & Upaplutayonivyapat & Kaphajayonivyapat & Yoni arsha & Phiranga \\
\hline Kaphajapandu & Atticharanayonivyapat & & & Upadamshe \\
\hline Rajayakshma & Kaphajashotha & & \\
\hline & Kaphajapremeha & & & \\
\hline & Krumi & & & \\
\hline & & & \\
\hline
\end{tabular}

\section{Treatment}

1. Eradication of cause.

2. Kaphagnha medication.

3. Varti- (Vaginal tablet)

4. Yonidhavan.

5. Yoni Dhupana

1. Eradication of cause:

Vaginal discharge is a symptom found in various diseases. Hence, the curative treatment for any type of vaginal discharge is to remove the underlying disease. All other methods are more or less, useful to relieve the symptom The modern science also agrees that treatment of vaginal discharge varies with the cause. Foreign bodies must be removed, infections and neoplasms should be treated accordingly.

2. Kaphaghna medication:

Kaphasamana treatment- If discharge per vagina is especially white in colour, Pichilasrava, Kanduyukta then it is due to vitiated Kapha, the main aim would be to bring Kapha to its normal state naturally. For this various Kaphaghna drugs are advised. The main characteristics of these drugs are Ruksha and Ushna.
3. Varti-Vaginal tablets.

Varti Kalpana is identical to vaginal tablets. The same purpose is served by using Kalka, Pichoo or Pottali. All these methods are employed for a local action of the drug.

4. Yonidhavan-

It deals with altered $\mathrm{pH}$ of vagina thus not favouring microorganism invasion.

5. Yoni-Dhupan-

It deals with the following actions-

Srotoshodana- Clears off the passage.

KaphaghnaKledaghna-Absorbs secretions

Rakshoghna- Bactericidal and Antiseptic.

It is specially mentioned for Upapluta and Kaphaja Yoni but can be used in all cases of Styäna and PichchilSträvas.Commonly used drugs for medicinal fumigation with Sarala, Guggulu and Yava (Hordeum vulgareLinn) mixed with Ghrita should be done after oleating the vaginal canal.

Treatment of vaginal discharge with different yonivyapat

\begin{tabular}{|c|c|c|}
\hline Name & Modern interpretation & Treatment \\
\hline 1. kaphaj Yonivyapat & Vaginitis & $\begin{array}{l}\text { 1. Ruksha (dry) and Ushna (hot)treatment. } \\
\text { 2.Trivrut kalka dharana } \\
\text { 3.Pipalaydi varti Arkavarti }{ }^{16} \text { (c.ch.30/70-72) } \\
\text { 4. Lodhrasava. }\end{array}$ \\
\hline Upapluta & White discharge & 1. Rohitakakalka. \\
\hline
\end{tabular}




\begin{tabular}{|c|c|c|}
\hline Yonivyapat & & $\begin{array}{l}\text { 2. Lodhrasava } \\
\text { 3. Dhatakaydi tail pichoo }{ }^{17}\end{array}$ \\
\hline $\begin{array}{l}3 . \quad \text { Atyananda } \\
\text { yonivyapat } \\
\text { Acharana (Charaka) } \\
\text { Vipluta (vagabhat) }\end{array}$ & Puritis vulvae & $\begin{array}{l}\text { 1. Dhatakayadi tail } \\
\text { 2. Uttarabasti with oil prepared with Jivaniya varga dravya. } \\
\text { 3. Sneha pichu dharana with Sneha prepared by sallaki, jingini, jambut- } \\
\text { vak, dhava and valkala. }\end{array}$ \\
\hline 4.Aticharna & Simple erosion & 1. Sneha pichu \\
\hline 5.karnini & Chronic cervicitis & Shodhanvartikushta, pippali, arka, saindhava, bastamruta \\
\hline
\end{tabular}

\section{DISCUSSION}

A woman during her life span may have different types of discharges per vagina. The vagina serves as a passageway between the outside of the body and the inner reproductive organs. The $\mathrm{pH}$ balance of the vagina is acidic, which discourages infections from occurring. This acidic environment is created by naturally occurring bacteria. A healthy vagina produces secretions to clean and regulate itself, like saliva which cleans and regulates the environment of the mouth. Any interference with the balance of vaginal secretions sets up an environment conducive to infection.

Ayurveda explains both oral and local procedures. Treatment of Vaginal discharge is mainly based on the use of drugs which are having a predominance of Kashaya rasa and Kapha-shamaka properties. Therefore, the drugs of Kashaya rasa dominance are mainly used locally and internally. For this treatment, sthanikachikitsa plays an important role here. The vaginal wall is very well suited for the absorption of drugs since it contains a vast network of blood vessels. The drugs used for sthanikachikitsa act by exerting their antiseptic, antimicrobial, antifungal, antiinflammatory and analgesic actions. Here proper Sthanikachikitsa with proper internal medicines gives potentially good results in the treatment of vagina.

\section{CONCLUSION}

Yonigatastravas not only disturbs the physical health of women but also affects their mental status. Ayurveda has given several effective remedies to treat Vaginal discharge. These Ayurvedic formulations have given miraculous results and should be used in treating various gynaecological conditions associated with Vaginal discharge. Once the aetiology has been ruled out it is very easy to treat the women with satisfying results and there is no recurrence of the disease.

\section{REFERENCES}

1. Achaya Charaka, Charaka Samhita (Uttarardha) Chikitsasthana; Yonivayapad Charaka - Chandrika Hindi Commentary by Dr BrahmanandTripathi Reprint: 2008 Varanasi, Chaukhambha Sanskrit Series, Chapter30/13 P.N. 1011

2. AchayaCharaka, Charaka Samhita (Uttarardha) Chikitsasthana; Yonivayapad Charaka - Chandrika Hindi Commentary by Dr BrahmanandTripathi Reprint: 2008 Varanasi, Chaukhambha Sanskrit Series, Chapter30/13 P.N. 1011

3. Astangahridaya, (Uttertantra) Chikitsasthana; Chapter30/13 Yonivayapad Hindi commentary Brahmananda Tripathi, reprint: 2013, ChaukhambhaPublication, Uttaratantra, chaper33/44 p.no. 1132

4. Sushruta Samhita, Utttara Tantra KavirajAmbikadutta Shastri, part 2, Chaukhambha Publication, reprint2013, 38/9, 11

5. AchayaCharaka, Charaka Samhita (Uttarardha) Chikitsasthana; Yonivayapad Charaka - Chandrika Hindi Commentary by Dr BrahmanandTripathi Reprint: 2008 Varanasi, Chaukhambha Sanskrit Series, Chapter30/13 P.N. 1011

6. Achārya Vagbhața, Uttartantra Prologue by Prof. JyotirMitra, Edited by Dr Shivprasad Sharma, Ashtanga Samgraha, Sasilekha commentary by Indu, Chaukambha Sanskrit Series, Uttaratantra, Chapter 33/49 P.No.896

7. Vaidya Jadavji Trikamji Achārya, Susruta Saṃhita, Nibandhasamgraha Commentary of Shri Dalhanacārya and Nyayacandrikapanjika of Sri Gayadasacārya, Chaukamba Orientalia Publishers, Varnasi, Uttarasthana; Ninth Edition; Chapter 38/ 16; P.No.669

8. Vaidya Jadavji Trikamji Achārya, Susruta Saṃhita, Nibandhasamgraha Commentary of Shri Dalhanacārya and Nyayacandrikapanjika of Sri Gayadasacārya, 
Chaukamba Orientalia Publishers, Varnasi, Uttarasthana; Ninth Edition; Chapter 38/ 16; P.No.669

9. Vaidya Jadavji Trikamji Achārya, Susruta Saṃhita, Nibandhasamgraha Commentary of Shri Dalhanacārya and Nyayacandrikapanjika of Sri Gayadasacārya, Chaukamba Orientalia Publishers, Varnasi, Uttarasthana; Ninth Edition; Chapter 38/ 16; P.No.669

10. Achārya Vagbhața, Uttaratantra Prologue by Prof. JyotirMitra, Edited by Dr Shivprasad Sharma, Ashtanga Samgraha, Sasilekha commentary by Indu, Chaukambha Sanskrit Series, Uttaratantra, Chapter 33/48,49P.No.896

11. Vaidya Jadavji Trikamji Acārya, Charaka Saṃhita, Ayurveda pradeepika commentary by Sri Cakrapāṇidatta, prologued by Prof. R.H. Singh, ChaukambaSubharatiPrakashanVarānasi; Reprint 2016, Chikitsasthana; Chapter 30/21-22; P.No.635

12. Charaka Samhita, Pandit Kashinath Sastri, Dr Gourakhnath Chaturvedi, reprint-2012, Choukhambha Publication, NidanSthan 3/14

13. Shri Bhavamisra Bhavarakasa, vidyotinihindi Commentary by Bhisagratna pandit Shri Brahma Sankara Misra Chaukhambasanskritstansthan Reprint Ninth Edition 2005 Chikitsa 69/1 P.N. 763

14. Shri Madhavakare Madhavanidana - Madhukoshsanskrit Commentary by M.M. Sri. VijayaRaksita\& Srikantahadarte, Edition Reprint 2012 Chawkhambhasanskrit, Uttaratantra 47/ 2 P.N.267.

15. Shri Bhavamisra Bhavarakasa, vidyotinihindi Commentary by Bhisagratna pandit Shri Brahma SankaraMisra Chaukhambasanskritstansthan Reprint Ninth Edition 2005 Chikitsa 69/1 P.N. 763

16. Acharya Charaka, Charaka Samhita (Uttarardha), Charaka - Chandrika Hindi Commentary by Dr Brahmanand Tripathi Reprint: 2008 Varanasi, Chaukhambha Sanskrit Series, Chikitsasthana; Chapter 30/72 P.N. 1023

17. Acharya Charaka, Charaka Samhita (Uttarardha), Yonivaypad Charaka - Chandrika Hindi Commentary by Dr Brahmanand Tripathi Reprint: 2008 Varanasi, Chaukhambha Sanskrit Series, Chikitsasthana; Chapter 30/68/ 80 P.N. 1024

18. Acharya Charaka, Charaka Samhita (Uttarardha) Yonivyapat, Charaka - Chandrika Hindi Commentary by Dr Brahmanand Tripathi Reprint: 2008 Varanasi, Chaukhambha Sanskrit Series, Chikitsasthana; Chapter 30/109 P.N. 1030.

\section{Source of Support: Nil Conflict of Interest: None Declared}

How to cite this URL: Nisha Baban Pawshe $\mathcal{L}$ Tinku-Ganesh P. Khalache: Ayurvedic Concept of Vaginal Discharge: (Yonigata Strava. International Ayurvedic Medical Journal \{online\} 2021 \{cited November 2021\} Available from: http://www.iamj.in/posts/images/upload/2802_2807.pdf 